\title{
THE POLICY FAILURES OF CENTRAL GOVERNMENTS DURING EAST BENGAL CRISIS, 1947-71
}

Kashif Iqbal*

\begin{abstract}
The incident of 1971 is a historical concern. Both wings of Pakistan were united at the time of the creation of Pakistan but some policies that were adopted after the creation of Pakistan were inadequate to resolve the growing differences between the both wings. Writers are divided regarding the causes of the Fall of Dhaka. Indian involvement has been highlighted frequently and it is also said that East Bengal was on the distance of $1000 \mathrm{~km}$ from West Pakistan. Apart from these causes, this study will highlight a new perspective regarding the separation of East Bengal. From 1947 to 1971 the central governments of Pakistan took some measure regarding formulating policies and the policies were not sufficient to bring people of the both wings closer. Thus, the major policies and their consequences would be analysed in this paper. Further, this research would be a new one in a sense that there would be a general description of the policies from both wings.
\end{abstract}

Keywords: Central government; policy failures; elections; major decisions; PPP and Awami League; fall of Dhaka

\section{Introduction}

The regional conflict of 1947 between East Bengal and Western provinces was brought up at its zenith at the time of 1970 elections by the central government when East Bengal insisted complete autonomy from Centre under the political guidance of Awami League. The regional abhorrence was there at the creation of Pakistan as well as before the creation between East Bengal and Western provinces but the differences were suppressed under the shelter of Muslim-brotherhood. Concisely speaking, there were three factors or three main areas of conflicts where the central governments of Pakistan failed such as economy, culture and politics. Gradually, the three basic factors inculcated a sense of national self-determination into the minds of the deprived. In this regard, some unpragmatic policy decisions brought the regional conflict at the verge of collapse of the unity of Pakistan and finally separation. Likewise, the six-point formula (1966) was presented the dragged the attention of the people towards constitutional demand of autonomy and regionalism by Shaikh Mujib (East Bengal's political leader and Head of Awami league since 1963). Practically speaking, the 1970 elections made Awami league a winner but the results were avoided by Western power oriented leaders. Thus, the long standing regional conflict of two wings rose with new enthusiasm and fallouts. The conflict ended with the fall of Dhaka. The Fall of Dhaka was not mere an event that took place in December 1971 but it shook the very basis of Two Nation Theory/Muslimbrotherhood. The Two Nation Theory echoed unity among the Muslims of India without

* Kashif Iqbal, M.Phil. Scholar, Department of History, Quaid-I-Azam University, Islamabad 
considering even boundary but Fall of Dhaka proved it wrong while breaking Muslims in two parts. The fragmentation of the East Bengali's was of the result of conflicts related to economy, culture and politics that took a real shape after the 1970 general elections. On the basis of ethnicity, East Bengal's political arena was focused on regional politics. 1970 elections invoked Bengali political consciousness. As compared to West Pakistan, East Pakistanis were relatively more aware of politics. Thus, they suddenly realized injustice committed by West Pakistan. The regional issue was roused nationally and it took armed stance. When the political issue went into the hands of army, it seemed of the slipping of East Bengal. The 1970 elections provided a plat form to the politicians of the both wings to induce people of their areas the regional differences to avail their personal political advantages. Among the benefiters Awami League and Pakistan Peoples Party were on the front line.

After 1970 elections, both Pakistan Peoples Party (PPP) and Awami League (AL) emerged as the victorious parties in their respective wings (West and East Wings) of Pakistan. The Six Point formula of AL greatly contributed in mobilizing the Bengali masses in the favor of the party. Shaikh Mujib called his six points as a tool to strengthen Pakistan. Mujib began campaigning on his six point formula and Z.A Bhutto (Head of Pakistan Peoples Party and foreign minister in President Ayub's regime) highlighted the Kashmir and India related issues. Election results were in the favor of Mujib but there occurred a deadlock owing to the conflicting stances taken by Mujib and Bhutto regarding the constitutional and political set up in the country. Mujib wanted to frame the constitution based on his provincial autonomy while Bhutto was in the favor to have a strong center. Yahya tried to bridge the gulf between the two main streams but all in vain. The inflexible outlook of both parties brought East Bengal on the verge of collapse. Both leaders were ardent on their stances. Bhutto issued political statements while saying," We are here, you are there". In this way, Mujib demanded right of rule but West Wing was of the view that victory from one unit cannot be endorsed easily due to demands of power and governance from West wing political leaders. The political stalemate enhanced major regional conflicts leading to the Fall of Dhaka. This term paper will highlight the major political and ethnical conflicts that occurred after the 1970s elections. There would be discussion over the causes that created the conflict and in last the lessons would be also touched that Pakistan learned from this historical loss. The road leads East Bengal towards regionalism and then the Fall of Dhaka. Regionalism and Fall of Dhaka are completely linked. Linkage would be traced in the perspective of genesis of the separatism.

\section{Culture, Economy, and Politics: Where Central Governments failed}

There might be many factors that caused unrest in East Bengal but economy, culture and politics these were the main factors that developed a sense of regionalism in the minds of East Bengalis, the three factors were long lasting and prominent in the whole historical breakup. Further, there were many other grievances that were not dealt properly. Javed Iqbal also highlights the main areas where gap remained till the Fall of Dhaka. in the words of Javed Iqbal, 
Many factors, such as the geographical and socio-cultural differences between the two wings, the language issue, the economic disparity, and exploitation of the East Pakistan, disparity in civil service and armed forces, differences over constitution making, the degeneration of Muslim league and the rise of regional Bengali Parties, and the political grievances and alienation of East Pakistan, were responsible for the process of decay that finally resulted in the loss of East Pakistan and the dismemberment of the country. ${ }^{1}$

\section{Culture: area of Alienation}

Regionalism explains a group in a region having strong sense of same history and culture. Cultural/Ethnic separatism has been linked with two academic approaches to fully grasp the beginning of these separatist movements. First the finding of the forces that boost up the separatist inclinations and the second is to find the factor that compels a region to go at the distance to demand separate identity. The first approach demands to consider history for the historical forces that were responsible for the enhancing of regional trends in a particular time. On the other hand, the second approach stresses on elucidation with terms of space. ${ }^{2}$ There are other factors as well which formulate regionalism while other regions do not take such steps in a real sense. Same situation can be found in the famous statement of Abul Mansur in Constituent Assembly in 1956, he reaches at the conclusion that his claim of just two nations in Pakistan before 1971 would be wrong. Abul Mansur said,

These two wings differ in all matters, excepting two things, namely, that they have a common religion, barring a section of the people in East Pakistan, and that we achieved our independence by a common struggle. There are only two points which are common to both the wings of Pakistan. With the exception of these two things, all other factors, viz., the language, the tradition, the culture, the costume, the custom, the dictionary, the calendar, the standard time, particularly everything is different. There is, in fact, nothing common in the two wings, particularly in respect of those factors which are the sine qua non-to form a nation... in reality it is not one country and we are going to form one state out of two countries. ${ }^{3}$

Abul Mansur's statement seems right. East Bengal and Western provinces were different in all major areas but the basis on which Bengal agreed to be consolidated with Eastern provinces are worth mentioning. Bengal's main leadership agreed due to the political structure that was passed in the shape of Lahore Resolution (1940). In which the federal form of government was the political future of united Pakistan. Federation is the form of government that can bear major differences between units. Further, the above-mentioned statement verily defines two cultural and geographical wings but apart from the two different wings, there were different major identities as well. such as Baloch, Sindhi,

\footnotetext{
${ }^{1}$ Javed Iqbal, "Separation of East Pakistan: Analyzing the Causes and Fixing the Responsibility," Pakistan Journal of History and Culture, XXIX, no.2 (2008): 1 .

${ }^{2}$ Donald L. Horowits, "Patterns of Ethnic Separatism, " Comparative Studies in Society and History, 23, no. 2 (April 1981), http;//links.jstor.org/sici?sici=0010-

4175\%28198104\%2923\%3A2\%3C165\%3APOES\%3E2.0.CO\%3B2-4 (accessed 04 October 2017).

${ }^{3}$ Abul Mansur Ahmad's speech in the Constituent Assembly of Pakistan, 16 January 1956, in Constituent Assembly (Legislature) of Pakistan Debate, 1816.
} 
Pashtun and Punjabi identities. In a nutshell, West Wing of Pakistan was not as united so was East Bengal at the cultural grounds at the time of 1970 elections. all the minor and major differences mentioned by Abul Mansur were present since the inception of Pakistan and these could be dealt. Unfortunately, economy, culture and politics were the issues that boosted up and shaped the minor and major issues. thus, the situation was further deteriorated. The strategy that marred the situation was of the use of hard power (use of military and other armed forces to lessen the severity of any violent situation). Joseph Nye (Father of the concept of Soft Power) suggests that all the violent or the movements that create unrest should be dealt with soft power. According to his research, soft power is the only way to tackle down all violent movements. He further defines that soft power relies mainly on three dimensions including culture, political values and foreign politics. ${ }^{4}$ In the case of East Bengal, West Pakistan's main stream political and military leadership applied all the means of hard power. Results that Pakistan faced were of the Fall of Dhaka.

\section{Language Controversy}

Political culture and culture of East Bengal was deeply rooted in the language. Lawrence Ziring said, "the Bengali love affair with their language involves a passionate ritual that produces emotional experiences seldom found in their part of the world". ${ }^{5}$ It was very idealistic tactic of the Muslim League's leadership to link Bengali with a "Hindu language". ${ }^{6}$ Although Jinnah said that for official use East Bengal's representatives can use the language of their choice ${ }^{7}$. Later, the linguistic affiliation of Bengalis with their language and the turning face of the west wing leaders to Bengali made the situation disturbed. In the first session of Constituent Assembly of Pakistan on 23 February 1948 Mr. Dharendranath Dutta (member of Constituent Assembly of Pakistan) moved an amendment to make Bengali language as official language of Pakistan including Urdu. Prime Minister Liaquat Ali Khan, Khawaja Nazim-Uddin, Mr. Ghazanfar Ali Khan, Mr. Tamizuddin and other members opposed the amendment then it was excluded. ${ }^{8}$ Further, Safdar Mahmood has observed, "the language controversy was dragged on unnecessarily due to the unwise policy of the Centre". This was an early endeavor to resolve the linguistic issue but West wing's mainstream political leadership turned its face. Khalid bin Saeed argued, "Abul Hashim who raised the demand for a separate state in the Council session of the All India Muslim League in 1946 on the plea that the Lahore resolution could be interpreted as an endorsement of two separate states." ${ }^{\prime 10}$ Thus, they always demanded autonomous homeland and presented Lahore Resolution as a proof of the honesty of their claim. Jinnah's visit and speech at Dhaka on 19 March 1948 was a step towards the lessening of the severity of the issue.

\footnotetext{
${ }^{4}$ Joseph Nye, Soft Power: The Means to Success in World Politics, (New York: Public Affairs, 2005), 1-20.

${ }^{5}$ Lawrence Ziring, Bangladesh from Mujib to Ershad: An Interpretive Study (Karachi: Oxford University Press, 1992), 4.

${ }^{6}$ Ian Talbot, Pakistan: A Modern History (Lahore: Vanguard Books, 1999), 77.

${ }^{7}$ Syed Humayun, Sheikh Mujib's 6-Point Formula (Karachi: Royal Book Company, 1995), 280.

${ }^{8}$ Safdar Mahmood, Divided Pakistan, (Lahore: Feroz Sons, 1984), 8.

${ }^{9}$ Ibid., 11 .

${ }^{10}$ Khalid Bin Sayeed, Politics in Pakistan: The Nature and Direction of Change (New York: Praeger Publishers, 1980), 66.
} 
Having failed to prevent the establishment of Pakistan, thwarted and frustrated by their failure, the enemies of Pakistan have now turned their attention to disrupt the state... these attempts have taken the shape principally of encouraging provincialism. As long as you do not throw off this poison in our body politic, you will never be able to weld yourself. ${ }^{11}$

Gradually, the differences took strong roots finally Pakistan was divided. Further, linguistic unity played a role to boast up the political grievances of the East wing. Even when Bengali was adopted as one of the state languages, Governor Monem Khan in Ayub's period tried to ban all the literature that was linked to Tagore. ${ }^{12}$

\section{Economy: The Basic Need}

All the sectors of any country need finance to run their departments. In the case of East Bengal, financial issues were one of the main issues that shaped political future of East Bengal. Financial differences laid down political differences while giving East wing leadership a chance to demand separation. When the majority province was neglected in the terms of finance, the question of deprivation comes up. Further, in Ayub's regime the industrial and agricultural reforms were only for West wing. ${ }^{13}$ From Prime Minister Liaqat Ali Khan to President Ayub Khan the financial condition of the East Bengal was left. Although President Yahya Khan took pragmatic measures yet leadership and governance crisis that emerged after 1970 elections were too grim to be tackled. The following chart will further throw light on the fund allocation issue and it would be cleared that during the five-year plan of Yahya, he focused on social justice and wanted to remove the disparities between East and West wing ${ }^{14}$ but it was too late to tackle the long-lasting issues.

\section{Development Outflow in the Public and Private Sectors}

\begin{tabular}{|l|c|c|}
\hline \multicolumn{2}{|c|}{ Percentage of the total Expenditure } \\
\hline Pakistan & East Pakistan & West \\
\hline $1950-51$ to 1954-55 & 20 & 80 \\
\hline $1^{\text {st }}$ Five Year Plan 1955-60 & 32 & 74 \\
\hline $2^{\text {nd }}$ Five Year Plan 1960-65 & 36 & 68 \\
\hline $3^{\text {rd }}$ Five Year Plan 1965-70 & 52.5 & 64 \\
\hline $4^{\text {th }}$ Five Year Plan 1970-75 & 26 & 47.5 \\
\hline
\end{tabular}

Source: Zaheer, Hasan, The Separation of the East Pakistan: The Rise and Realization of Bengali Muslim Nationalism, Karachi: Oxford University Press, 1994, 242.

\footnotetext{
${ }^{11}$ Mehmood, Divided Pakistan, 10

${ }^{12}$ Sayeed, Politics in Pakistan: The Nature and Direction of Change, 66.

${ }^{13}$ Lord Birdwood, A Continent Decides, (London: Robert Hale Ltd, 1953), 67.

${ }^{14}$ L F Rushbrook Williams, The East Pakistan Tragedy (New York: Drake Publishers INC, 1972), 33.
} 
The other main argument in this regard can be Tajuddin Ahmed's. Tajuddin in one of his interviews in Febrauary 1971 cleared financial complications. His interview has been quoted by Khalid bin Sayeed. Tajuddin said,

We have to resume trade with India.... We are being forced to import coal from China which costs us Rs. 172 per ton. We can import the same coal from India at Rs. 53 per ton. we use to produce our own cement in Sylhet but the raw material, limestone, used to come from Assam. that has been suspended since the war. West Pakistan industrialists sell cement to us at Rs. 12 to Rs. 16 per bag of cement. Our cement, ex-factoru, used to retail at Rs. 7 to 8. Indian cement is Rs. 8.50 per bag. India was the only buyer of low-quality jute. We can't sell that to India.... Hundreds of thousands of problems have been created in this way.... Any standard cloth from Japan would cost Rs. 2 per yard whereas West Pakistan cloth is sold in the protected market at Rs 6 per yard. They play havoc with bonus scheme". 15

These reservations were not dealt properly leaving the situation becoming controversial. This shows clearly that how financial issues enhanced cultural disparity between two wings. That was the central's policy to enhance trade between two wings but the policy failed due to unawareness of the main stream policy makers from the geographical facts that made East Bengal deprived of easy and cheap trade.

\section{Politics: The viable tool to disintegration}

Second Constituent assembly of 1956-58 had forty members from West Pakistan comprising twenty-eight members belonging to landlord backgrounds. While twenty members from East Pakistan were lawyers and eight were retired officials. ${ }^{16}$ West wing's hesitation towards the resolving of the acuteness of the conflict was unpredictable. Leadership and other actors were struggling to shut up East wing despite taking them into confidence. Further, geographically the two wings were placed on the distance of 1 thousand miles away from each other. Not to mention the geographical issue, the East wing was politically united while West wing lacked the characteristic. ${ }^{17}$

One of the main burning issues of the political representation was unresolved. East Bengal's political representation in mainstream politics was small as compared to West wing. Even East Bengal comprised more population than West wing's but they were less accommodated in cabinet. The following chart will further put the light on the differences;

\footnotetext{
${ }^{15}$ Khalid Bin Sayeed, Op.Cit., 69

${ }^{16}$ Mehmood, Divided Pakistan, 4

${ }^{17}$ Ibid., 4
} 
Composition of the Central Cabinets ${ }^{18}$

\begin{tabular}{|c|c|c|c|c|}
\hline $\begin{array}{l}\text { Head of the } \\
\text { Government }\end{array}$ & $\begin{array}{l}\text { Total strength } \\
\text { of the cabinets }\end{array}$ & W. Wing & E. Bengal & $\begin{array}{c}\text { Percentage of the } \\
\text { Bengalis }\end{array}$ \\
\hline $\begin{array}{c}\text { Liaqat. A. Khan } \\
1947-51\end{array}$ & 19 & 13 & 6 & 31.2 \\
\hline $\begin{array}{c}\text { Nazimuddin } \\
1951-53 \\
\end{array}$ & 15 & 9 & 6 & 40 \\
\hline $\begin{array}{l}\text { M. Ali Bogra } \\
1953-3\end{array}$ & 14 & 9 & 5 & 35 \\
\hline $1954-55$ & 16 & 9 & 7 & 44 \\
\hline $\begin{array}{c}\text { Mohammad Ali } \\
1955-56\end{array}$ & 17 & 10 & 7 & 41 \\
\hline $\begin{array}{c}\text { Suhrawardy } \\
1956-57\end{array}$ & 14 & 6 & 8 & 57 \\
\hline $\begin{array}{c}\text { Chundrigar } \\
1957 \\
\end{array}$ & 16 & 9 & 7 & 44 \\
\hline $\begin{array}{c}\text { F.K Noon } \\
1957-58 \\
\end{array}$ & 27 & 15 & 12 & 44.5 \\
\hline $\begin{array}{c}\text { Ayub Khan } \\
1958-60\end{array}$ & 12 & 9 & 3 & 25 \\
\hline $1960-62$ & 16 & 11 & 5 & 26 \\
\hline $1962-65$ & 17 & 9 & 6 & 47 \\
\hline $1965-69$ & 17 & 11 & 8 & 35 \\
\hline $\begin{array}{c}\text { Yahya Khan } \\
\text { 1969-Feb.1971 }\end{array}$ & 11 & 6 & 5 & 45.4 \\
\hline
\end{tabular}

Source: Mehmod, Safdar, The Deliberate Debacle, Lahore: Ashraf Sons, 1976, 44.

*: Includes the heads of government."

While observing the above representative differences, East Bengal's political sense of deprivation seems natural. Throughout political regimes, they were neglected even they were in majority. Thus, it was easy for Mujib to mold the grievances in his favor. Those who were in majority should have been given representation. The representative policy of the West failed leaving the united Pakistan divided.

The main practical problem that took place after the creation of Pakistan was the creation of a sense of provincialism. This created provincialism that gave opportunity to the Bengalis of raising slogan "Bengal for Bengalis". In the planned elections of 1954, Awami league took complete advantage of provincialism and cultural difference. ${ }^{19}$ The

\footnotetext{
${ }^{18}$ Safdar Mehmod, The Deliberate of Debacle (Lahore: Ashraf Sons, 1976), 44.

${ }^{19}$ Mehmood, Op.Cit., 9.
} 
policy failure of the central government can be observed from the behavior that Pakistani leadership played in 1949. In 1949 Suhrawardy wanted to attend a Constituent Assembly session but he was not allowed blaming of his alleged citizenship. ${ }^{20}$ Thus, the regional differences were slowly enhanced particularly by leadership from Ayub to Bhutto.

West Pakistan missed all opportunities to solve the harsh disparities of the both wings. Connor argued, "It is a truism that centralized communications and increased contacts help to dissolve regional cultural distinctions within a state such as the United States. Yes, if one is dealing not with minor variations of the same culture, but with two quite distinct and self-differentiating cultures, are not increased contacts between the two apt to increase antagonisms?"21 in this regard leadership vacuum cane into being.

\section{Six Points: United Pakistan's Dawn of Practical Political Policy Failure}

East Bengal's politics was dominated by Sher-e-Bangla A.K. Fazlul Haque, Maulana Abdul Hamid Khan Bhasani and Huseyn Shaheed Suhrawardy. After the demise of Fazlul Haque and Huseyn Shaheed Suhrawady, Maulana Bhasani and Shaikh Mujib became the main political figures of East Bengal. This was the reason that Mujib's six point had a power to sweep East Bengal in 1971 general elections. Shaikh Mujib was the person who practically highlighted the issue of regionalism by accusing West wing as target. Further, "Greater success may be attained through steps that conduce to the development of a deeper sense of mutual awareness and responsiveness among etc.lencapsulated cultural units." Easton. ${ }^{22}$ Thus, when West wing seemed helpless while lessening the political issues and there was no way out to cultural and regional harmony, Shaikh Mujib presented his Six Point agenda before a meeting at Lahore in February 1966. His six point were based on regional autonomy. He opposed concentrating of powers by federal. The constitution of Pakistan has become "a cloak for rule by the few who were able to concentrate powers in their hands" ${ }^{23}$ His political stance was matured regarding Bengali politics. The cultural and economic differences already made people aware of the differences. Shaikh Mujib said in one of his interviews, "I do not like to be a colony of anyone any more. Our government is fighting for a referendum in Kashmir. Let it have a referendum here on the six point and it will find eighty-five per cent of the people behind me". ${ }^{24}$ It should be perceived that all the major parties of that time opposed his Six Point Formula. Such as Muslim League (Council), nizam-e-Islam, Jamaat-eIslami and West Pakistan branch of Awami League openly accused of the formula at first but when West wing was seen unserious, the political parties began to support six point. Six Point Formula was one of the starting point of practical political opposition of West wing's political authority. This shows that East Wing openly decided to make itself free and sovereign in the sense of their issues. On the other hand, Bhuyian said that the AL's

\footnotetext{
${ }^{20}$ Mohammad H. R Talukdar, ed., Memoirs of Huseyn Shaheed Suhrawardy: with a Brief Account of his Life and Work (Karachi: Oxford University Press, 2009), 36.

${ }^{21}$ Walter Connor, "Self-Determination: The New Phase, "World Politics 22 (October 1967): 49-50.

${ }^{22}$ David Easton, A Systems Analysis of Political Life (New York: Wiley, 1965), 250.

${ }^{23}$ Hassan Rizvi, Internal Strife and External Intervention: India's Role in the Civil War in East Pakistan (Lahore: Progressive Publishers, 1981), 72.

${ }^{24}$ The London Observer, 24 April 1966. Quoted in, Safdar Mahmood. Pakistan Divided: Study of the Factors, Leading to the Breakup of Pakistan in 1971 (Lahore: Institute of Islamic Culture, 19890, 47.
} 
creation was the consequent of "frustration caused by the closed-door policy of Muslim League. ${ }^{, 25}$ Further, Badruddin in another statement said that NAP presented its fourteen points to counter Mujib's six point and named it "program of national liberation". ${ }^{26}$ Here it can be claimed that just PPP was not the ardent opponent of Awami League but the National Awami Party and other political parties were in the race as well. The National Awami party had capability to become national party due to its leadership. It included the main leaders from both wings such as from East Wing it included Mualana Bhashani and from West wing it included Abdul Ghafar Khan, Pir of Manki Sharif, Mian Iftikharuddin, G. M. Syed, and Mahmoodul Haq Usmani. The party divided in 1964 because of political decisions. Some followed Moscow while others were in favor of Peking. ${ }^{27}$

In this scenario, the Six Point became an ideology for the East Bengalis. On 22 July 1970, Mujib said, "West Pakistani exploiters had looted the wealth of Bengal in the name of Islam and other cheap slogans and in the process of exploitation, the foremost freedom fighters like Hussain Shahid Suhrawardy and Fazlul Haq were harassed... and such harassments and deprivations will continue if the people fail to unite under the Six Point and eliminate the exploiters of Bangladesh". ${ }^{28}$ Keeping the Mujib's above statement, anyone can analyze the political situation prevailing in East Bengal at the time of 1970 elections. Mujib's six point were controversial. This was the reason that political chaos came out when West wing refused to transfer power to Awami League but six point formula was negotiable but efforts were not taken to negotiate on Six Point. It could be dealt with soft power despite hard power. Further, in 1974 warfare in Iraq, Iran's full support was with Kurds but the Kurds wanted autonomy. The point is that the demand of autonomy can be shifted from autonomy to independence ${ }^{29}$ and in the case of East Bengal it was explicit but the main part was played by Western wings while providing East Bengal a base to go from regionalism to separatism.

\section{0s General Elections: New Era of Political Decisions and Separation}

After taking power, General Yahya Khan announced final date for the elections as of 17 December 1970. Pakistan was divided theoretically during 1970 general elections. That was the period in which there was no any political force that could unite the two wings. The reason of the division lied in history. According to Rounaq Jahan, during Ayub regime there could not develop any sense of national level politics. The Jamat-i-Islami, the Council Muslim League, and the Pakistan Peoples Party (PPP) were mainly West Pakistan based. On the other hand, Awami League represented only East Bengal. ${ }^{30}$ Moreover, Shaikh Mujib's election campaign was based on his six-point formula and the Six Point Formula was for the people of Bengal only. Political platform was ripe for

${ }^{25}$ Abdul Wadud Bhuiyan, Emergence of Bangladesh and Role of Awami League (New Delhi: Vikas Publishing house Pvt Ltd, 1982), 23.

${ }^{26}$ Badruddin Umar, the Emergence of Bangladesh: Rise of Bengali Nationalism Vol. II. (1958-1971) (Karachi: Oxford University Press, 2006), 111.

${ }^{27}$ Rounaq Jahan, Pakistan: Failure in National Integration (New York: Columbia University Press, 1972), 139.

${ }^{28}$ The Ittefaq, July 23, 1970. Quoted in Humayun, Sheikh Mujib’s 6-Point Formula, 304.

${ }^{29}$ Donald L. Horowits, "Patterns of Ethnic Separatism, " Comparative Studies in Society and History, 23, no. 2 (April 1981), http;//links.jstor.org/sici?sici=0010-

4175\%28198104\%2923\%3A2\%3C165\%3APOES\%3E2.0.CO\%3B2-4 (accessed 04 October 2017).

${ }^{30}$ Rounaq Jahan, Op.Cit., 141. 
Awami League. Shaikh Mujib distinguished the worth of his six point and that of the prevailing political grievances of East Bengal. Therefore, his was the politics of nationalism. The political situation of East Bengal during elections has been rightly depicted by Chaudhary;

\begin{abstract}
In political talks and election campaigning, Mujib and his followers were free to preach the idea of Bangladesh to every house in every village without hindrance: cries of Joy Bangla! (Victory of Bangladesh) were heard everywhere.... Mujib's election campaign was the same as Jinnah's 1945-1946 for the establishment of Pakistan. AL was the only representative party in East Pakistan; the other parties could hardly have organized any meetings, and when they did the militant Awami Leaguers would disrupt them. The young and student followers of Mujib were freely carrying the gospel of Bangladesh everywhere in East Pakistan. On August 14, 1970- Pakistan's Independence Day- the students of Dacca University had displayed a new map showing the creation of Bangladesh, and the flag of the emerging country was prominently displayed at a meeting to celebrate Independence Day. ${ }^{31}$
\end{abstract}

In 1970 East Bengal faced destructions of flood. Apart from flood, East Bengal struck a cyclone of severity to the costal belt of East Bengal on November 12. President Yahya Khan avoid any further delay of the announced election date. This was the decisive moment as well. It was claimed by East Bengal that due care was not shown towards East Bengal during the floods and cyclone. It was also said that central government, Navy and Air Force were not serious to help East Bengal. Contrary to the mentioned statements, Rushbrook said,

...in the course of two visits to Pakistan in the Spring and early Summer of 1971, I made it my business to enquire into such allegations as these. I found that the Defence Forces deeply resented them; they had worked day and night and to the very limit of their endurance, to bring relief, I found plenty of impartial testimony from foreign relief workers who had succeeded in getting into the field of operations about the sterling work that the Defence Forces had been doing; their devotion, I was told was beyond all praise. The Forces, too, had their own stories to tell. They were often obliged to bury corpses themselves, because survivors refused to undertake this work unless they were paid ten rupees for each burial. ${ }^{32}$

All the efforts that Yahya made were ignored and just the Awami League's point of view was highlighted in the international media ${ }^{33}$ due to pre-planned intentions to de-moralize West wing in the eyes of East Bengal to get votes in the general elections. Moreover, one can oppose the Yahya's decision of not to change the election date when East Bengal was stuck in cyclone but it cannot be said that West wing was in rest during the flood and cyclone. Unfortunately, flood and cyclone were become lead-ins for Mujib to inculcate the idea of separatism. Shaikh Mujib was not in a position to accept any sympathy from west wings due to his heroic image in East Bengal.

${ }^{31}$ G.W. Choudhary, The Last Days of United Pakistan (London: C. Hurst \& Company, 1974), 98-99.

${ }^{32}$ Williams, The East Pakistan Tragedy, 37

${ }^{33}$ Ibid., 38. 
Election preparations were started at the end of 1970 all the country over. Justice Abdus Satta became chief Election Commissioner while two judges were his colleagues, one from East Bengal and one from Western provinces. 24 parties took part in the elections. $56,500,000$ qualified electors were there and more than 135,000,000 ballot papers were available. 16,000 polling stations were in East Bengal and 14,000 were in West Pakistan. $^{34}$ This was the figurative description of election scenario at the time of elections.

Mujib got 160 seats out of 162 seats in East Bengal while in Western provinces of Pakistan there were various political parties who got different numbers of seats but more seats were in the part of Bhutto's PPP. PPP got 82 out of 138 in West wing's total seats, in Sindh 32 out of 60 seats, in NWFP of that time now Khyber-Pakhtunkhwa 3 seats out of 40 seats, in the province of KPK the larger group was of the NAPs who got 13 seats and Qayum section of Muslim League got 10 seats. Further, in Baluchistan 8 seats were in the part of Wali Khan out of 20 seats.

\section{Conclusion}

Since the inception of Pakistan, the issue existed but it cannot be said that the issue of regionalism was so deep as it could not be tackled. Quaid-i-Azam Mohammad Ali Jinnah pointed out the issue while visiting East Bengal to resolve language problem. He knew the intensity of the grievances of East Bengalis. Unfortunately, leadership crisis suppressed East Bengal's economic, cultural as well as political rights. Thus, literary and political conscious East Bengalis took the notice. All the five-year plans except Yahya's clearly show the injustice that was done with East Bengali's. Ayub's political as well as economic initiatives were focused on Western provinces. Before Ayub, politics was in the hands of puppets they could not do anything for East Bengalis. Resultantly, deprived East Bengalis were sheltered under Mujib who at first demanded provincial autonomy but elections of 1970 changed Mujib's stance. Mujib was refused to take political powers. Zulfiqar Ali Bhutto was in the opposition of Mujib. This political conflict dragged the issue towards army. These policy initiatives were unpragmatic and failed. These policy failures were the main causes of the fall of Dhaka.

Army was considered a final step but it was not in real sense because the conflict was due to power sharing thus power sharing was turned into power suppressing. On March 25, 1971 army started operation to undertake handmade burning situation. But the issue was of a political kind. Hence, army put its last hit and the East Bengal went in the hands of separatism. Here army should be seen a symbol of force. The issue was of dialogue. Force only forced the issue to go into the path of separation. The conflict was tried to be tackled under the shelter of Yahya. He compelled Bhutto and Mujib to settle down the issue politically. But political greediness did not allowed leaders from West wing to rationally tackle the stance of Mujib. Finally, stress ridden people of Bengal united under Mujib and his six-point formula and the journey of unity between East Bengal and Western provinces was departed leaving harsh memories. The Fall of Dhaka was the policy failures of Pakistan. After the demise of Jinnah, all the taken policies could not

${ }^{34}$ Ibid., 41. 
please the East Bengal. Regional centric approach of the regions became too strong to raise the slogan of separatism. In the words of Javed Iqbal, "in December 1971, East Pakistan became the independent state of Bangladesh as a result of a movement of Bengali separatism". ${ }^{35}$

\section{Bibliography}

Aziz, K.K. Party Politics in Pakistan. Islamabad: National Commission on Historical and Cultural Research, 1976.

Birdwood, Lord. A Continent Decides. London: Robert Hale Ltd, 1953.

Bhuiyan, Abdul Wadud. Emergence of Bangladesh and Role of Awami League. New Delhi: Vikas Publishing house Pvt Ltd, 1982.

Burke, S. M. Pakistan's Foreign Policy: An Historical Analysis, Karachi: Oxford University Press, 1973.

Chopra, Pran. India's Second Liberation. Delhi: Vikas Publishing House, 1973.

Choudhury, G. W. The Last Days of United Pakistan. London: Hurst and Company, 1974.

Easton, David. A Systems Analysis of Political Life. New York: Wiley, 1965.

Humayun, Syed. Sheikh Mujib's 6-Point Formula. Karachi: Royal Book Company, 1995.

Husain, Syed Shahid. What was Once East Pakistan. Karachi: Oxford University Press, 2010.

Jahan, Rounaq. Pakistan: Failure in National Integration. New York: Columbia University Press, 1972.

Mehmood, Safdar. Pakistan Divided. Lahore: Ferozsons, 1984.

Nehru, Jawaharlal. The Discovery of India. New York: The John Day Co, 1946.

Rizvi, Hasan. Internal Strife and External Intervention: India's Role in the War in East Pakistan. Lahore: Progressive Publishers, 1981.

1974.

. The Military and Politics in Pakistan. Lahore: Progressive Publishers,

Salik, Siddique. Witness to Surrender. Karachi: Oxford University Press, 1977.

Sayeed, Khalid Bin. Politics in Pakistan: The Nature and Direction of Change. New York: Praeger Publishers, 1980.

${ }_{35}$ Javed Iqbal, "Separation of East Pakistan: Analyzing the Causes and fixing the Responsibility," Pakistan Journal of History and Culture, XXIX, no.2 (2008): 1. 
Siddiqi, A.R. East Pakistan the Endgame: An Onlooker's Journal 1969-1971. Karachi: Oxford University Press, 2004.

Talbot, Ian. Pakistan: A Modern History. Lahore: Vanguard Books, 1999.

Talukdar, Mohammad H. R., ed. Memoirs of Huseyn Shaheed Suhrawardy: with a Brief Account of his Life and Work. Karachi: Oxford University Press, 2009.

Umar, Badruddin. The Emergence of Bangladesh. Karachi: Oxford University Press, 2006.

Williams, L F Rushbrook. The East Pakistan Tragedy. New York: Drake Publishers INC, 1972.

Zaheer, Hasan. The Separatism in East Pakistan: The Rise and Realization of Bengali Muslim Nationalism. Karachi: Oxford University Press, 1994.

Ziring, Lawrence. Bangladesh from Mujib to Ershad: An Interpretive Study. Karachi: Oxford University Press, 1992.

$\overline{\text { University Press, }} 1971$.

. The Ayub Khan Era: Politics in Pakistan 1958-69. Syracuse: Syracuse

\section{Articles and Journals}

Connor, Walter. "Self-Determination: The New Phase, "World Politics, 22 (October 1967): 49-50.

Donald L. Horowits, "Patterns of Ethnic Separatism, " Comparative Studies in Society and History, 23, no. 2 (April 1981), http;//links.jstor.org/sici?sici=0010-

$4175 \% 28198104 \% 2923 \% 3 \mathrm{~A} 2 \% 3 \mathrm{C} 165 \% 3$ APOES\%3E2.0.CO\%3B2-4 (accessed 04 October 2017).

Iqbal, Javed. "Separation of East Pakistan: Analyzing the Causes and fixing the Responsibility," Pakistan Journal of History and Culture, XXIX, no.2 (2008): 1.

The Ittefaq, July 23, 1970. Quoted in Humayun, Sheikh Mujib's 6-Point Formula, 304.

The London Observer, 24 April 1966. Quoted in, Safdar Mahmood. Pakistan Divided: Study of the Factors, Leading to the Breakup of Pakistan in 1971 (Lahore: Institute of Islamic Culture, 1989, 47. 